\title{
Gênero Pimenta: aspectos botânicos, composição química e potencial farmacológico
}

PAULA, J.A.M. ${ }^{1 *}$; REIS, J.B. ${ }^{1}$; FERREIRA, L.H.M. ${ }^{1}$; MENEZES, A.C.S. ${ }^{2}$; PAULA, J.R. ${ }^{3}$

${ }^{1}$ Universidade Estadual de Goiás, Curso de Farmácia *joelma.paula@ueg.br ${ }^{2}$ Universidade Estadual de Goiás, Programa de Pós-Graduação em Ciências Moleculares, Br 153, Km 98, Campus Henrique Santillo, CEP: 75001-970, Anápolis-Brasil ${ }^{3}$ Universidade Federal de Goiás, Laboratório de Pesquisa de Produtos Naturais, Setor Universitário, Praça Universitária, CEP: 74001-970, Goiânia-Brasil

RESUMO: A família Myrtaceae possui representantes de grande interesse medicinal e o gênero Pimenta é um dos que merecem destaque. A maioria das espécies desse gênero é nativa da América Central, com exceção da Pimenta pseudocaryophyllus (Gomes) L. R. Landrum, nativa nas regiões centro-oeste e sudeste do Brasil. O presente estudo teve como objetivo revisar aspectos botânicos, químicos e farmacológicos descritos na literatura sobre o gênero Pimenta. Os dados foram obtidos de artigos originais e revisões indexadas nas bases Periódicos Capes, ISI Web of Knowledge, Bireme e SciELO. As espécies desse gênero podem ser arbustivas ou arbóreas, possuem pelos unicelulares, folhas usualmente coriáceas, inflorescência em dicásio ou panícula e são distinguidas, principalmente, pela estrutura do ovário. As propriedades farmacológicas são conferidas, principalmente, pelos óleos essenciais que são constituídos, na maioria, por derivados fenilpropanóides, monoterpenos, aldeídos monoterpênicos e alcoóis monoterpênicos. Dentre as propriedades farmacológicas apresentadas por espécies desse gênero destacam-se as anti-hipertensivas, anti-inflamatórias, analgésicas, antimicrobianas e antioxidantes. Das quinze espécies de Pimenta conhecidas, a Pimenta dioica (L.) Merrill e a Pimenta racemosa (Miller) J. Moore são as espécies de maior importância econômica e, por esse motivo são as mais estudadas do ponto de vista químico e farmacológico.

Palavras-chave: Myrtaceae, Pimenta, óleos essenciais, composição química, atividades farmacológicas

ABSTRACT: Pimenta genus: botanical aspects, chemical composition and pharmacological potential. The family Myrtaceae has representatives of great medical interest, and the genus Pimenta deserves attention. Most species of this genus are native to the Central America, except Pimenta pseudocaryophyllus (Gomes) L. R. Landrum, which is native to the Central-West and Southeast Brazilian Regions. This study aimed to review botanical, chemical and pharmacological aspects described in the literature for Pimenta genus. Information was obtained from original papers and reviews indexed in the databases "Periódicos Capes", ISI Web of Knowledge, "Bireme" and SciELO. This genus can present shrubs or trees, which have unicellular hairs, usually coriaceous leaves and dichasium or panicle inflorescence, and are mainly distinguished by the ovary structure. The pharmacological properties are mostly due to essential oils, mainly consisted of phenylpropanoid, monoterpene, monoterpenic aldehyde and alcohol derivatives. Among these properties, antihypertensive, anti-inflammatory, analgesic, antimicrobial and antioxidant ones are highlighted. Of the fifteen known Pimenta species, Pimenta dioica(L.) Merrill and Pimenta racemosa (Miller) J. Moore have the greatest economic importance and consequently have been the most chemically and pharmacologically studied

Key words: Myrtaceae, Pimenta, essential oils, chemical composition, pharmacological activities

\section{INTRODUÇÃO}

A utilização de vegetais no tratamento de doenças e na recuperação da saúde é um método terapêutico natural que está presente de forma marcante na cultura popular (Rodrigues \& Carvalho, 2001), fato que tem levado órgãos oficiais de saúde pública no Brasil à implantação de Políticas que viabilizem a utilização racional, segura e eficaz de plantas medicinais e fitoterápicos (Brasil, 2006a; 2006b).

Recebido para publicação em 19/02/2009

Aceito para publicação em 12/04/2010

Rev. Bras. PI. Med., Botucatu, v.12, n.3, p.363-379, 2010. 
Até por volta do século XIX as plantas medicinais e derivados consistiam na base da terapêutica. Com o advento da pesquisa científica, muitas substâncias puderam ser isoladas das plantas e serviram de modelos para a produção de fármacos. Atualmente, cerca de $25 \%$ dos fármacos empregados nos países industrializados provêm, de forma direta ou indireta, de produtos naturais, principalmente de plantas superiores (Yunes \& Cechinel Filho, 2001). Tanto nesses países quanto nos países em desenvolvimento, materiais vegetais são utilizados na produção de preparações caseiras para tratar as mais diversas doenças, e ainda como matéria-prima para a indústria farmacêutica, o que representa proporção substancial do mercado global de medicamentos (WHO, 1998). Estima-se que $80 \%$ da população mundial fazem uso das plantas como primeiro recurso terapêutico (Silva \& Cechinel Filho, 2002).

Esforços multidisciplinares têm propiciado ainda acréscimo no número de pesquisas em torno das atividades farmacológicas e toxicológicas das plantas, bem como, grande preocupação com a identificação exata, a pureza e outros parâmetros que assegurem a qualidade de matérias-primas de origem vegetal (Schulz et al., 2002; Yunes \& Cechinel Filho, 2007).

A família Myrtaceae, uma das mais importantes da flora brasileira, possui representantes de grande interesse medicinal. Essa família apresenta distribuição pantropical e subtropical, possui cerca de 130 gêneros e 4000 espécies. No Brasil são 23 gêneros e aproximadamente 1000 espécies. As espécies pertencentes a essa família apresentamse na forma de árvores ou arbustos, com o córtex do tronco esfoliante (presença de ritidoma); folhas geralmente opostas, simples, com margem inteira, coriáceas ou subcoriáceas, com pontos translúcidos que denotam a presença de grande número de cavidades secretoras de óleos essenciais, peninérveas com nervura marginal; flores geralmente brancas, bissexuadas, actinomorfas, diclamídeas; frutos geralmente na forma de baga, drupa, cápsula ou núcula (Joly, 2002; Judd et al., 1999; Landrum \& Kawasaki, 1997; Souza \& Lorenzi, 2005).

Dentre os representantes de interesse medicinal dessa família destacam-se as espécies do gênero Pimenta, conhecidas especialmente pela importância econômica atribuída à Pimenta dioica (L.) Merrill (allspice) e à $P$. racemosa (Miller) J. Moore (bay tree). A $P$. dioica é utilizada principalmente como condimento ou especiaria, sendo que as populações da América Central e do Caribe utilizam as folhas para o tratamento da hipertensão arterial, diabetes, obesidade, transtornos digestivos, dismenorréia e dores abdominais (Suárez et al., 1997b). É ainda, um dos ingredientes básicos de uma bebida denominada Pru muito popular na ilha de Cuba, à qual são atribuídas propriedades refrescantes e medicinais (Volpato \& Godinez, 2004). A P. racemosa é utilizada na medicina popular para o tratamento de reumatismo, dor de dente, dores abdominais, febre, pneumonia e gripe (García et al., 2004).

A maioria das espécies é nativa do Caribe e América Central exceto uma delas, $P$. pseudocaryophyllus (Gomes) L.R. Landrum, que é nativa do Brasil, encontrada nos biomas mata atlântica e cerrado (Landrum \& Kawasaki, 1997; The New York Botanical Garden, 2004). É popularmente conhecida como pau-cravo ou craveiro e as folhas são muito utilizadas pela população do interior do estado de Minas Gerais, Brasil, no preparo de chás antigripais (Paula et al., 2008) e, no município de Campos do Jordão, São Paulo, Brasil, no preparo de chás calmantes, reguladores da digestão e menstruação (Nakaoka-Sakita et al., 1994).

Estudos científicos têm demonstrado que espécies do gênero Pimenta apresentam propriedades anti-hipertensivas, antiinflamatórias, analgésicas, antimicrobianas e antioxidantes (Bara \& Vanetti, 1997/ 1998; Fernández et al., 2001; García et al., 2004; Kikuzaki et al., 1999; Suárez et al., 2000). Muitos desses estudos corroboram as utilizações etnofarmacológicas desse gênero.

Tendo em vista a importância da etnobotânica de espécies do gênero Pimenta, em especial ao que se refere à etnofarmacologia, o presente trabalho teve como objetivo revisar os principais aspectos botânicos, químicos e farmacológicos descritos na literatura. Estes dados poderão subsidiar estudos multidisciplinares futuros envolvendo espécies desse gênero e contribuirão para análise crítica da utilização pela população, com vistas à preservação dos valores culturais, à preservação das espécies vegetais nos respectivos biomas e à promoção do uso racional de espécies vegetais como recurso terapêutico.

\section{Fontes dos dados}

Para a realização desse trabalho buscou-se artigos originais e revisões indexados nas bases Periódicos Capes, ISI Web of Knowledge, Bireme e Scielo. Utilizaram-se as palavras-chave Myrtaceae e Pimenta. Buscaram-se ainda dados relevantes contidos em livros nacionais e internacionais que tratam de assuntos, tais como botânica, química de produtos naturais, fitoterapia e farmacognosia. Não houve restrição no que se refere ao ano de publicação.

\section{Aspectos botânicos do gênero Pimenta}

\section{Aspectos macroscópicos}

Segundo Landrum (1986) e Landrum \& Kawasaki (1997), as espécies do gênero Pimenta são, na maioria, arbóreas e podem crescer até 20 metros. Algumas espécies podem se apresentar como

Rev. Bras. Pl. Med., Botucatu, v.12, n.3, p.363-379, 2010. 
arbustos. Estão confinadas ao Caribe e à América Central, exceto a espécie P. pseudocaryophyllus, que é nativa da região sudeste brasileira.

De acordo com Landrum (1986), são destacadas as seguintes características gerais para o gênero: o indumento pode variar de espécie para espécie e a densidade é útil na distinção das espécies; os pelos podem ser esbranquiçados, amarelados ou marron-avermelhados, unicelulares, simples ou simetricamente dibraquiados; as folhas são persistentes, usualmente coriáceas, podendo em alguns casos serem submembranosas, as nervuras laterais são, na maioria, proeminentes e, com frequência, fazem ângulo reto com a nervura central; as inflorescências são basicamente de dois tipos, dicásio e panícula, podendo apresentar de 3 a 100 flores, a panícula ocorre quando a flor central do dicásio é substituída por um ramo; o ramo tem um ou mais nódulos férteis que terminam em um dicásio; as flores podem ser pentâmeras ou tetrâmeras, os cálices podem estar fechados ou divididos em quatro ou cinco partes; as bractéolas podem se apresentar lineares, triangulares ou oblongo-ovadas com até 3 $\mathrm{mm}$ de comprimento, são decíduas antes ou durante a antese; os estames podem se apresentar em número de 16 - 170, esbranquiçados, dobrados no centro do botão fechado, e no botão jovem os filamentos são mais longos que as anteras; as pétalas são esbranquiçadas e suborbiculares. Landrum (1986) destaca ainda que as estruturas do ovário e da placenta são muito importantes taxonomicamente na distinção das espécies. Os ovários podem ser uniloculares ou biloculares e todas as espécies têm placenta subapical. Em algumas espécies, o número de óvulos é reduzido para um ou dois e a placenta não protrai, enquanto que em outras espécies 0 número de óvulos fica em torno de 3 a 9 por lóculo e a placenta sofre protrusão adquirindo aspecto semelhante a uma haste. Os frutos são bagas globosas, apresentam de uma a duas sementes arredondadas cuja cobertura pode ser membranosa, cartilaginosa ou dura. O embrião da semente possui hipocótilo espesso e cotilédones relativamente pequenos, podendo apresentar-se em forma de "C" ou enovelado.

As características apresentadas acima são compatíveis com as descritas por Joly (2002), Judd et al. (1999) e Landrum \& Kawasaki (1997) para a família Myrtaceae.

Segundo Landrum (1986), as espécies do gênero Pimenta apresentam odores característicos, principalmente nas folhas, devido a presença de óleos essenciais que conferem sabor picante e odor forte. A Pimenta dioica e a Pimenta racemosa são as espécies de maior importância econômica. Em alguns casos, uma espécie pode ter mais que um odor comum. O odor da Pimenta jamaicensis lembra o cheiro de cânfora e de limão.

Em Landrum (1986) são registradas as espécies e principais características. Pimenta adenoclada (Urban) Burret habita as regiões litorâneas de Cuba, sendo pequena árvore de até 6 metros de altura, diferindo das demais por apresentar flores tetrâmeras; folhas densamente cobertas por pelos dibraquiados, usualmente esbranquiçados na superfície abaxial e um óvulo em um ovário unilocular. A Pimenta cainitoides (Urban) Burret, arbusto ou árvore de pequeno porte parece ser restrita ao interior de Cuba, distinguindo-se das demais espécies por apresentar flores tetrâmeras; dois óvulos em um ovário unilocular; folhas cobertas com pelos dibraquiados e marron-avermelhados na superfície abaxial e por habitar o interior do país. Enquanto, Pimenta dioica (L.) Merrill ocorre principalmente em florestas localizadas a 700 metros do nível do mar no México, Guatemala, Belize, Honduras, Nicarágua, El Salvador, Cuba e Jamaica. É altamente cultivada e a distribuição pode ter expandido. Trata-se de árvore que pode atingir 20 metros de altura, tendo vários nomes populares, mas é comumente chamada de "pimenta inglesa" (allspice), "pimento", "pimenta da Jamaica" e "malaqueta". Essa espécie é a mais importante do gênero e distingue-se por apresentar flores tetrâmeras; ovários biloculares com um ou dois óvulos por lóculo; inflorescência em panícula; fragrância picante; folhas elípticas a oblongas, subcoriáceas a submembranosas.

A Pimenta ferruginea (Grisebach) Burret, espécie endêmica cubana pouco conhecida, aparentemente é árvore pequena restrita a regiões litorâneas, distingue-se por apresentar ovário unilocular com um óvulo; folhas cobertas de pelos dibraquiados na superfície abaxial e com papilas na superfície adaxial de onde emergem glândulas. A Pimenta filipes (Urban) Burret, espécie endêmica de Cuba, habita savanas e regiões litorâneas. Nessas regiões é chamada de "limoncillo" e "pimientica". Trata-se de pequena árvore ou arbusto e distingue-se das demais espécies por ser essencialmente glabra e ter inflorescência dicasial com pedúnculo de 0,3 $\mathrm{mm}$ de largura. A Pimenta guatemalensis (Lundell) Lundell, árvore de casca lisa, bem distribuída nas florestas tropicais da América Central, da Guatemala ao Panamá, é chamada de "guayabillo", na Guatemala e de "jamaica", na Costa Rica. Pode atingir de 5 a 20 metros de altura, apresenta flores pentâmeras e ovários uniloculares ou até ovários sem lóculos, é a única do gênero que apresenta indivíduos com ovários sem lóculo. Superficialmente, ela é similar à Pimenta dioica, mas se distingue por possuir flores pentâmeras e folhas com ápice acuminado. A Pimenta haitiensis (Urban) Landrum, arbusto ou pequena árvore endêmica de locais secos e pedregosos no sudoeste da República Dominicana pode atingir de 1

Rev. Bras. PI. Med., Botucatu, v.12, n.3, p.363-379, 2010. 
a 5 metros de altura e os nomes locais são "malaqueta" (República Dominicana) e "malaquette" (Haiti). É muito usada como condimento e aromatizante. Essa espécie distingue-se pelas flores pentâmeras; ovários biloculares ou triloculares com 3 - 7 óvulos por lóculo, em placenta que se projeta para o exterior. De todas as espécies não cultivadas de Pimenta, a $P$. haitiensis apresenta um dos mais atrativos e fortes aromas. A Pimenta jamaicensis (Britton \& Harris) Proctor tem distribuição restrita às regiões montanhosas da Jamaica, geralmente em altitudes acima de $600 \mathrm{~m}$, pode atingir de 3 a 10 metros de altura, é chamada em seu habitat de "wild pimento" e é usada como lenha para fogueiras. Pode ser confundida com a Pimenta dioica. O que as diferencia são algumas características, tais como, folhas $(P$. jamaicensis - coriáceas, $P$. dioica - subcoriáceas e submembranosas), frutos ( $P$. jamaicensis - frutos ovóides, $P$. dioica - frutos globosos), fragrância ( $P$. jamaicensis - semelhante ao aroma do limão e do eucalipto, P. dioica - odor picante), dentre outros fatores. A Pimenta obscura Proctor, pequena árvore de até 8 metros de altura, encontrada em florestas no interior de regiões montanhosas da Jamaica, conhecida localmente como "wild pimento" distinguese por apresentar flores tetrâmeras; ovários biloculares ou triloculares com um óvulo por lóculo; folhas subcoriáceas ou submembranosas; inflorescência em forma de panícula com até 25 flores. Assemelha-se à Pimenta dioica e à Pimenta jamaicensis.

A Pimenta odiolens (Urban) Burret, espécie de distribuição restrita ao interior cubano, conhecida localmente como "Palo de cincha", é árvore de pequeno porte distinguível das demais espécies pelo cálice completamente fechado. A Pimenta oligantha (Urban) Burret, espécie encontrada apenas em Cuba, é árvore pequena distinguida das demais espécies pela presença de flores tetrâmeras; ovários biloculares com um óvulo por lóculo; inflorescência do tipo dicásio e por ser essencialmente glabra. Assemelha-se à $P$. dioica, apesar de as inflorescências e as folhas da $P$. oligantha serem menores. A Pimenta podocarpoides (Areces) Landrum localiza-se no interior cubano. Tratase de pequena árvore ou arbusto de até oito metros de altura distinguida por suas folhas estreitas 15 vezes mais compridas que largas; pela inflorescência em dicásio com pequenas flores que possuem de dezesseis a vinte estames. A Pimenta richardii Proctor, árvore de doze a quinze metros de altura conhecida apenas em duas localidades no interior da Jamaica, em uma área de floresta e rochas calcárias, pode ser distinguida por suas flores tetrâmeras; ovários uniloculares ou biloculares com um óvulo por lóculo; folhas rigorosamente coriáceas e inflorescência globular compacta em panícula. É a espécie de Pimenta menos conhecida na Jamaica.

Landrum (1986) descreve, ainda, que
Pimenta racemosa (P. Miller) J. W. Moore, árvore de até doze metros de altura, distinta pelas flores pentâmeras e ovários biloculares contendo de quatro a nove óvulos por lóculo, possui cinco variedades. A Pimenta racemosa var. racemosa é provavelmente nativa das Pequenas Antilhas, Porto Rico e Cuba. Conhecida como "bay" e "bay tree". Amplamente cultivada nos trópicos americanos. Suas folhas são elípticas; oblongas ou obovadas; medem de 4,5 $16,5 \mathrm{~cm}$ de comprimento e 2,9- $7 \mathrm{~cm}$ de largura; essencialmente glabras; têm um forte odor picante ou semelhante ao limão. A Pimenta racemosa var. grisea (Kiaerskou) Fosberg é árvore usualmente encontrada a $800 \mathrm{~m}$ abaixo do nível do mar na ilha Hispaniola, em Porto Rico e Tortola. Conhecida comumente na República Dominicana como "ozua". As folhas são elípticas; oblongas ou obovadas; medem de 3,5-10 cm de comprimento e $2,5-6 \mathrm{~cm}$ de largura; densamente cobertas por pelos na superfície abaxial; apresentam odor de limão. A Pimenta racemosa var. hispaniolensis (Urban) Landrum é espécie endêmica da ilha Hispaniola a $950-1800 \mathrm{~m}$ de altitude, possui folhas elípticas a subloculares (raramente lanceoladas), que medem de 2,2 - 5 (10) cm de comprimento e 1,5 - $3 \mathrm{~cm}$ de largura, essencialmente glabras. A Pimenta racemosa var. ozua (Urban et Ekman) Landrum é endêmica da região centro norte da ilha Hispaniola, possui folhas elípticas a oblongas que medem de 5,4 - 10,3 (16) $\mathrm{cm}$ de comprimento e $3-4,5 \mathrm{~cm}$ de largura; glabras ou esparsamente pubescentes. $O$ nome popular dessa variedade é "ozua". Possui um forte odor semelhante ao eucalipto. A Pimenta racemosa var. terebinthina (Burret) Landrum é restrita aos arredores da Península Samaná, na República Dominicana, possui folhas estreitamente elípticas a estreitamente oblongas que medem de 4,5-10,5 cm de comprimento e 1,5-2,7 cm de largura, glabras ou esparsamente pubescentes.

A única espécie do gênero Pimenta nativa na América do Sul, encontrada nas regiões montanhosas litorâneas do Brasil (Rio de Janeiro à Santa Catarina) e na Região Centro-Oeste, é a Pimenta pseudocaryophyllus (Gomes) L.R. Landrum. Conforme Landrum (1986) trata-se de arbusto ou árvore cuja altura pode variar de um a dez metros, distinguida pelas flores tetrâmeras; ovários biloculares contendo de três a seis óvulos por lóculo e cobertura muito dura da semente. É a única espécie pertencente às Myrtaceae que combina embrião espiralizado e intumescido com capa de semente dura.

P. pseudocaryophyllus é separável em três variedades regionais. A Pimenta pseudocaryophyllus var. pseudocaryophyllus é árvore de pequeno porte típica de florestas e áreas montanhosas do sudeste do Brasil. Esta espécie é conhecida localmente como, "Iouro-cravo", "craveiro-do-mato" e "chá-de-bugre".

Rev. Bras. Pl. Med., Botucatu, v.12, n.3, p.363-379, 2010. 
Esses nomes também são usados para outras variedades dessa espécie. Possui folhas de coloração prateada na superfície abaxial; estreitamente elípticas, que medem de 4,5 - $11 \mathrm{~cm}$ de comprimento e 1,4 3,6 cm de largura; o ápice é agudo a acuminado; a base é cuneada a acuminada; o pecíolo mede 1 - 2 $\mathrm{mm}$ de largura e 5 - $13 \mathrm{~mm}$ de comprimento; as inflorescências apresentam-se em dicásio ou panícula de, usualmente, sete a quinze flores. A Pimenta pseudocaryophyllus var. fulvescens (A. P. de Canolle) Landrum é pequena árvore ou arbusto que se localiza em regiões secas no centro sul do Brasil. Existem alguns exemplares na Bolívia. Possui folhas ovais a amplamente elípticas, que medem de 7 - $13(22) \mathrm{cm}$ de comprimento e 3,7-7,3 cm de largura, de coloração marrom-avermelhada na superfície abaxial; o ápice é obtuso a arredondado; a base é arredondada a cuneada ou obtusa; o pecíolo mede 1 - $3 \mathrm{~mm}$ de largura e 10 - $22 \mathrm{~mm}$ de comprimento; as inflorescências em dicásio ou panícula contêm de sete a quinze flores. A Pimenta pseudocaryophyllus var. hoehnei (Burret) Landrum é pequena árvore confinada na região florestal litorânea do sudeste do Brasil, de Santa Cataria a São Paulo. Possui folhas obovadas, elípticas, elípticas-oblongas, que medem de 2,5-5,6 cm de comprimento e 1,3-2,8 cm de largura; o ápice é arredondado, obtuso ou emarginado; a base é acuminada a cuneada; o pecíolo mede 2 - 7 $\mathrm{mm}$ de comprimento e $1 \mathrm{~mm}$ de largura; as inflorescências apresentam-se, usualmente, em dicásio com, no máximo, três flores.

\section{Aspectos microscópicos}

São escassos os estudos que abordam características morfo-anatômicas das espécies do gênero Pimenta. Rebollar \& Quintanar (1998) descreveram a morfo-anatomia da madeira de $P$. dioica em estudo no qual analisavam madeiras de espécies arbóreas abundantes e tradicionalmente usadas no estado de Quintana Roo, México. Verificaram que a madeira de $P$. dioica apresenta poros de distribuição difusa, exclusivamente solitários e numerosos, de diâmetro tangencial muito pequeno. Os elementos de vaso são muito curtos (120 - $240 \mu \mathrm{m})$, rodeados por traqueídes vasicêntricas retangulares, as paredes apresentam pontuações areoladas alternas e placa perfurada simples. O parênquima axial é estreito e reticulado com uma só fileira de células. Apresenta cristais rombóides. Os raios são uniseriados e multiseriados (1 - 3), as fibras são do tipo limbriforme de diâmetro mediano e de paredes muito grossas (6 $10 \mu \mathrm{m})$.

Paula et al. (2006), ao realizarem o estudo farmacognóstico da casca de P. pseudocaryophyllus, registraram que o floema dessa espécie caracterizase pela alternância de células vivas com células esclerificadas de paredes polilameladas (Figura 1-
A). Em secção transversal são visíveis raios parenquimáticos multisseriados e idioblastos portadores de cristais prismáticos solitários de oxalato de cálcio (Figura 1-A). Em secção longitudinal tangencial e longitudinal radial o esclerênquima é composto por esclereides, fibras/fibroesclereídes e células pétreas, e os idioblastos, portadores de cristais prismáticos, distribuem-se em séries (Figuras 1-B e 1-C). O ritidoma acha-se constituído por várias peridermes sequenciais que englobam tecidos (Figura 1-D).

Paula et al. (2008), em estudo farmacognóstico das folhas de P. pseudocaryophyllus, verificaram que essas são hipoestomáticas com estômatos predominantemente anomocíticos. Há grande quantidade de tricomas unicelulares alongados na superfície abaxial. As paredes anticlinais das células da epiderme abaxial, em vista frontal, apresentam-se espessas e sinuosas (Figura 2A). Há cavidades secretoras contendo compostos lipídicos que se exteriorizam para as duas epidermes, porém são mais abundantes na superfície adaxial (Figura 2-B) e as células epidérmicas adaxiais, em vista frontal, revelam dimensões variadas e paredes anticlinais espessas, predominantemente retas a onduladas (Figura 2-C). O mesofilo está representado pelos parênquimas paliçádico e lacunoso (Figura 2-B). O parênquima paliçádico é formado por células alongadas compactamente dispostas em duas ou três camadas. O parênquima lacunoso é formado por células globosas frouxamente distribuídas em aproximadamente seis camadas. Ao longo do mesofilo, principalmente na região do parênquima lacunoso, há uma enorme quantidade de idioblastos portadores de cristais prismáticos ou drusas (Figura 2-B).

\section{Metabólitos secundários identificados e isolados de espécies do gênero Pimenta}

As espécies do gênero Pimenta mais estudadas do ponto de vista fitoquímico e farmacológico, por causa da relevância econômica e etnobotânica, são a $P$. dioica e a $P$. racemosa. Recentemente tem-se despertado no Brasil, o interesse pelo estudo fitoquímico e farmacológico da P. pseudocaryophyllus.

O grupo de metabólitos de interesse medicinal encontrado com maior freqüência no gênero Pimenta é o dos óleos essenciais. O que tem levado muitos pesquisadores a se dedicarem em estudos de identificação e quantificação dos componentes de óleos essenciais de espécies desse gênero (Tabela 1). Porém outros metabólitos secundários também têm sido descritos, tais como, saponinas, flavonóides e taninos (Tabela 1). As estruturas químicas da maioria desses compostos encontram-se nas Figuras 3 e 4. 

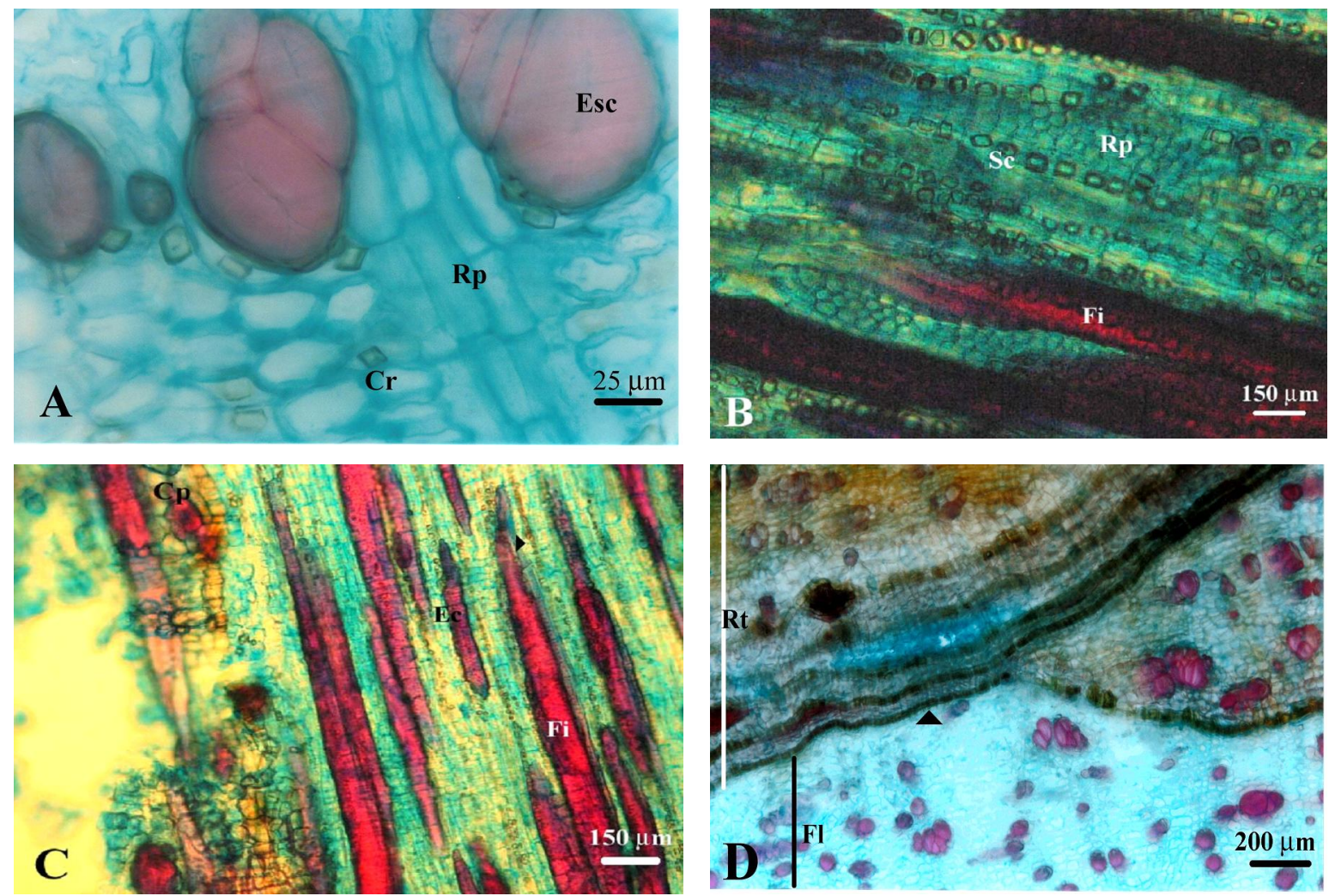

Legenda: $\mathbf{C p}$. células pétreas; Cr. cristais prismáticos de oxalato de cálcio; Ec. esclereide; Esc. esclerênquima; Fi. fibras/ fibroesclereíde; FI. floema; Rp. raios parenquimáticos; Rt. ritidoma; Sc. série cristalífera; setas indicam série critalífera na Figura 1-C e periderme na 1-D. Fonte: Paula et al. (2006).

FIGURA 1. Secções transversais e longitudinais da casca de Pimenta pseudocaryophyllus. A. secção transversal demonstrando detalhes do floema. B. secção longitudinal tangencial da região do floema. C. secção longitudinal radial. $\mathbf{D}$. secção transversal demonstrando as regiões de floema e ritidoma.

Os dados descritos na Tabela 1 demonstram que os componentes majoritários dos óleos essenciais de espécies do gênero Pimenta são quimicamente constituídos, na maioria, por derivados fenilpropanóides (eugenol [2], metileugenol [8], transmetil isoeugenol, timol [22]), monoterpenos (1,8-cineol [4]), aldeídos monoterpênicos (neral [17], geranial [16]) e álcoois monoterpênicos (geraniol [19], linalol [18], $\alpha$-terpineol [11]).

A composição química dos óleos essenciais contribui significativamente para a determinação do potencial farmacológico atribuído às espécies vegetais e pode sofrer variações em consequência de fatores extrínsecos à biologia vegetal (ambientais ou edáficos) e/ou intrínsecos à biologia vegetal (fisiológicos e genéticos) (Cunha et al., 2005; Simões \& Spitzer, 2004). Nesse sentido, foi possível verificar diferença na abundância relativa dos componentes do óleo essencial em folhas de $P$. dioica macho e $P$. dioica fêmea em estudo realizado por Minott \& Brown (2007). Observou-se, ainda, a ocorrência de quimiotipos em espécimes identificados como $P$. racemosa var. racemosa, de Guadalupe. Análise do óleo essencial desses espécimes identificou diferenças referentes às características físicas e à composição química, sendo que dois quimiotipos apresentaram quantidades maiores de éteres fenólicos (eugenol [2], chavicol [24], estragol e metileugenol [8]) e um quimiotipo apresentou geranial [16] e neral [17] como componentes majoritários (Abaul et al., 1995).

\section{Aspectos farmacológicos e toxicológicos do gênero Pimenta}

A farmacologia pode ser definida como 0 estudo dos efeitos das substâncias químicas sobre a função dos sistemas biológicos (Rang et al., 2007). Uma planta medicinal ou o respectivo extrato, como qualquer outro medicamento, deve passar por um processo de validação, que inclui a comprovação da atividade farmacológica e da possível toxicidade em humanos (Lapa et al., 2008). Estudos dessa natureza propiciam a avaliação da segurança e eficácia de preparações medicinais à base de plantas e envolvem várias etapas, dentre as quais se destacam os ensaios biológicos pré-clínicos (Lapa et al., 2008).

No que se refere às espécies do gênero Pimenta, foram encontrados na literatura estudos de atividade biológica apenas para as espécies $P$. 

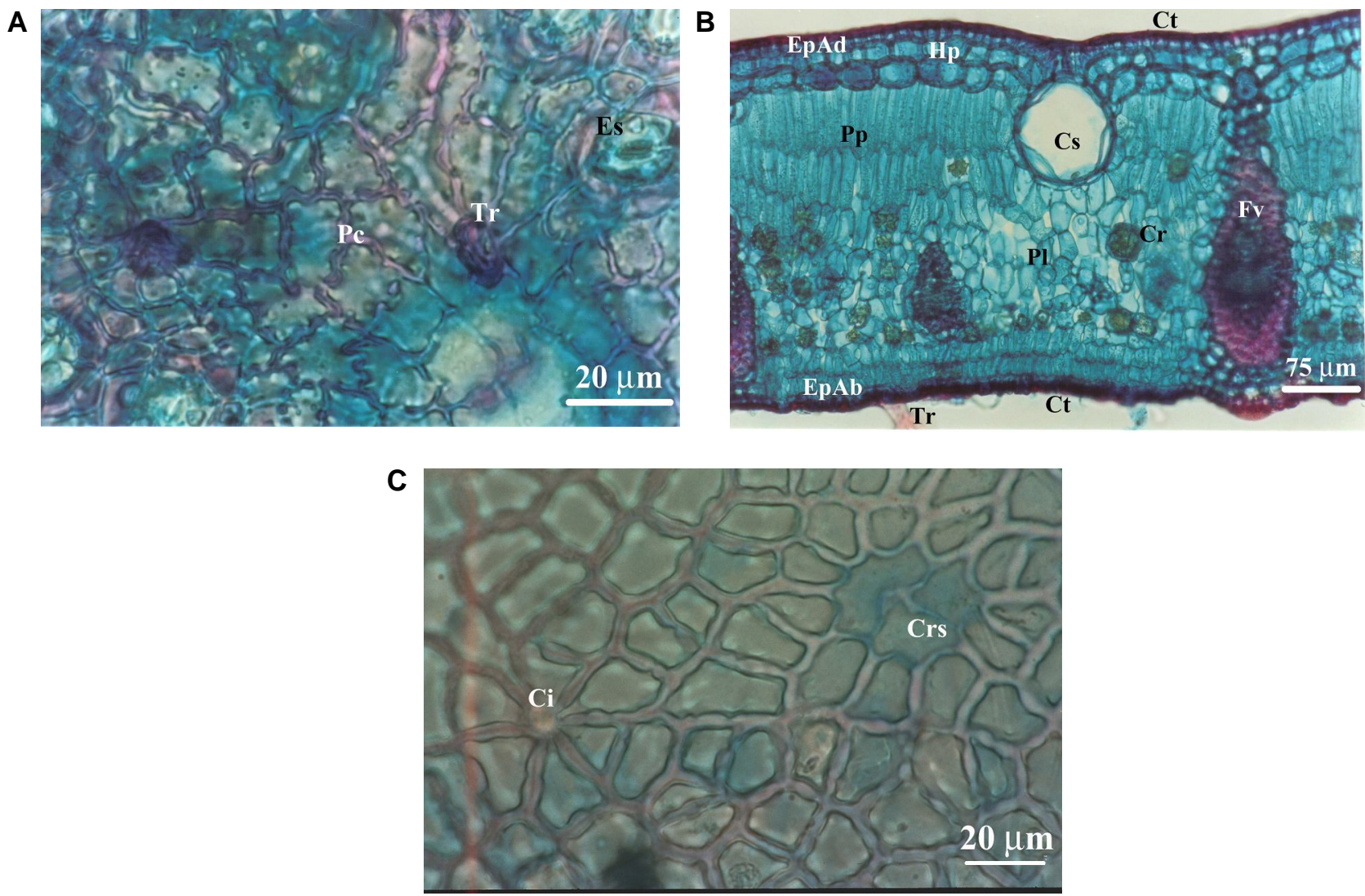

Legenda: Crs. célula que reveste cavidade secretora; Ci. cicatriz deixada após queda do tricoma tector; Pc. parede celular; Es. estômato; Cr. cristais - drusa; Cs. cavidade secretora; Ct. cutícula; EpAd. epiderme adaxial; EpAb. epiderme abaxial; Fv. feixe vascular; Hp. hipoderme; PI. parênquima lacunoso; Pp. parênquima paliçádico; Tr. tricoma tector. Fonte: Paula et al. (2008).

FIGURA 2. Secções paradérmicas e transversal da lâmina foliar de Pimenta pseudocaryophyllus. A. detalhe da epiderme abaxial da folha adulta. B. lâmina foliar em corte transversal. C. detalhe da epiderme adaxial da folha adulta.

TABELA 1. Principais compostos identificados em espécies do gênero Pimenta.

\begin{tabular}{|c|c|c|c|c|}
\hline Espécie & $\begin{array}{l}\text { Parte } \\
\text { planta }\end{array}$ & $\begin{array}{l}\text { Metabólito } \\
\text { secundário }\end{array}$ & $\begin{array}{c}\text { Compostos majoritários (percentual) } \\
\text { [estrutura FIGURAS } 3 \text { e 4] }\end{array}$ & Referências \\
\hline P. adenoclada & Folha & Óleo essencial & $\begin{array}{l}\text { Oxido de cariofileno (15,4\%) [1]; } \alpha \text {-muurolol } \\
(9,4 \%) ; \text { Il epóxido de humuleno }(7,6 \%) \text {. }\end{array}$ & Pino et al. (2002) \\
\hline \multirow[t]{7}{*}{ P. dioica } & Folha & Óleo essencial & $\begin{array}{l}\text { Eugenol }(66,38-79,24 \%) \text { [2]; } \beta \text {-cariofileno } \\
(0,97-7,10 \%)[3] . \\
\text { Eugenol }(31,14 \%)[2] ; 1-8, \text { cineol }(14,69 \%) \text { [4]; } \\
\text { a-humuleno (10,12\%) [5]. } \\
\text { Eugenol }(77,9 \%)[2]\end{array}$ & $\begin{array}{l}\text { Tucker et al. (1991c) } \\
\text { Hernández et al. (2003) } \\
\text { Marongiu et al. (2005) }\end{array}$ \\
\hline & & & $\begin{array}{l}\text { Eugenol (48\%) [2]; mirceno (27\%) [25]; } \\
\text { geraniol (10\%) [19]. }\end{array}$ & Oussalah et al. $(2006 ; 2007)$ \\
\hline & & Flavonóide & Quercetina [6] e catequina [7]. & Castro et al. (1999) \\
\hline & & & $\begin{array}{l}\text { Quercetina 3-O- } \beta \text {-Dglucoronide 6" metil ester } \\
\text { [26] e Quercetina 3-O-(2-O-galoil) glicosídeo } \\
\text { [26] }\end{array}$ & Nitta et al. (2009) \\
\hline & & $\begin{array}{l}\text { Tanino } \\
\text { condensado }\end{array}$ & - & Castro et al. (1999) \\
\hline & & Tanino & Galoilglicosídeos e taninos C-glicosídicos & Marzouk et al. (2007) \\
\hline & Fruto & Fenilpropanóide & $\begin{array}{l}\text { Treo-3-cloro-1-(4-hidroxi-3- } \\
\text { metoxifenil)propano-1,2-diol }\end{array}$ & Kikuzaki et al. (1999) \\
\hline
\end{tabular}


TABELA 1. Principais compostos identificados em espécies do gênero Pimenta.

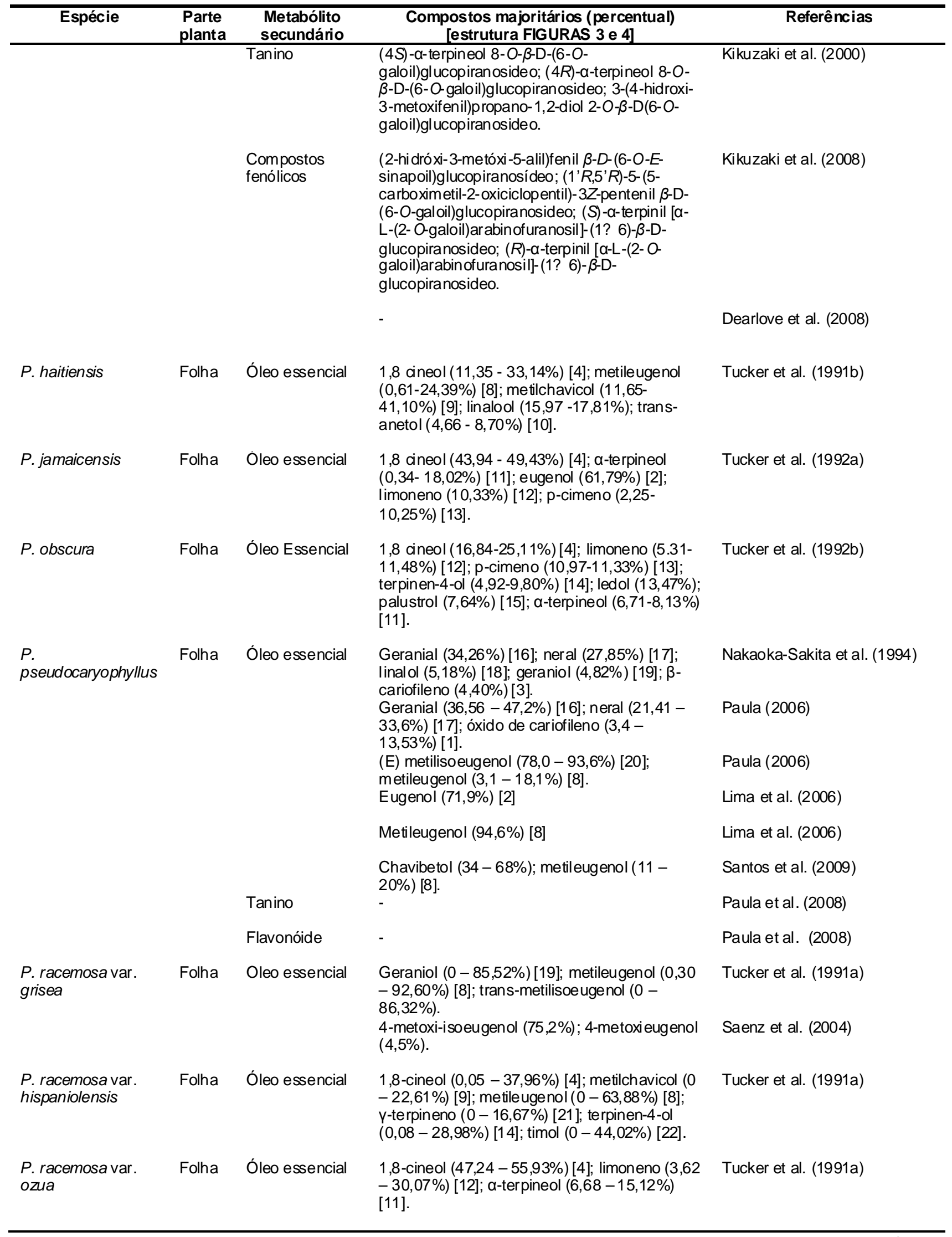


TABELA 1. Principais compostos identificados em espécies do gênero Pimenta.

\begin{tabular}{|c|c|c|c|c|}
\hline Espécie & $\begin{array}{l}\text { Parte } \\
\text { planta }\end{array}$ & $\begin{array}{l}\text { Metabólito } \\
\text { secundário }\end{array}$ & $\begin{array}{c}\text { Compostos majoritários (percentual) } \\
\text { [estrutura FIGURAS } 3 \text { e 4] }\end{array}$ & Referências \\
\hline & & $\begin{array}{l}\text { Saponina } \\
\text { triterpênica }\end{array}$ & Lupeol [23]. & Fernández et al. (2001) \\
\hline $\begin{array}{l}\text { P. racemosa var. } \\
\text { racemosa }\end{array}$ & Folha & Óleo essencial & $\begin{array}{l}\text { Chavicol }(0,01-15,51 \%) \text { [24]; eugenol }(44,41 \\
\text { - } 68,93 \%)[2] ; \text { metileugenol }(0-11,88 \%) \text { [8]; } \\
\text { mirceno (0,10 - 16,17\%) [25]. }\end{array}$ & Tucker et al. (1991a) \\
\hline $\begin{array}{l}\text { P. racemosa var. } \\
\text { terebinthina }\end{array}$ & Folha & Óleo essencial & $\begin{array}{l}\text { Acetato de } \alpha \text {-terpineol }(27 \%) \text {; } \alpha \text {-terpineol } \\
(20 \%) \text { [11]; metoxi eug enol }(12,6 \%) \text {. }\end{array}$ & Saenz et al. (2004) \\
\hline
\end{tabular}

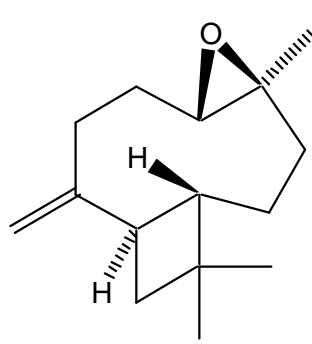

[1]<smiles>C=CCc1ccc(O)c(OC)c1</smiles>

[2]<smiles>C=C(CCC=C(C)C)C1CC(C)(C)C1CCC</smiles>

[3]<smiles>CC12CCC(O1)C(C)(C)C2</smiles>

[4]<smiles>CC1=CCCC(C)=CCC(C)(C)C=CC1</smiles>

[5]<smiles>C=CCc1ccc(OC)c(OC)c1</smiles>

[8]<smiles>O=c1c(O)c(-c2ccc(O)c(O)c2)oc2cc(O)cc(O)c12</smiles>

[6]<smiles>Oc1cc(O)c2c(c1)OC(c1ccc(O)c(O)c1)C(O)C2</smiles>

[7]<smiles>C=C(C)C1CC=C(C)CC1</smiles>

[12]<smiles>CC1=CCC(C(C)(C)O)CC1</smiles>

[11]<smiles>C=C(C)c1ccc(C)cc1</smiles>

[13]<smiles>C=CCc1ccc(OC)cc1</smiles>

[9]<smiles>C/C=C/c1ccc(OC)cc1</smiles>

[10]<smiles>CC1=CCC(O)(C(C)C)CC1</smiles>

[14]
[15]<smiles>CC1CCC2(O)C(C)CCC3C(C12)C3(C)C</smiles><smiles>CC(C)=CCC/C(C)=C/C=O</smiles>

[16]

FIGURA 3. Estruturas moleculares de compostos encontrados em espécies vegetais do gênero Pimenta. [1], óxido de cariofileno. [2], eugenol. [3], $\beta$-cariofileno. [4], 1-8, cineol. [5], $\alpha$-humuleno. [6], quercetina. [7], catequina. [8], metileugenol. [9], metilchavicol. [10], anetol. [11], $\alpha$-terpineol. [12], limoneno. [13], p-cimeno. [14], terpinen4-ol. [15], palustrol. [16], geranial. 


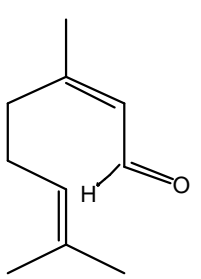

[17]<smiles>CC1=CCC(C(C)C)=CC1</smiles>

[21]<smiles>C=CC(C)(O)CCC=C(C)C</smiles>

[1 8]<smiles>Cc1ccc(C(C)C)c(O)c1</smiles>

[22]<smiles>CC(C)=CCC/C(C)=C/CO</smiles>

[19]<smiles>C/C=C/c1ccc(OC)c(OC)c1</smiles>

[20]<smiles>C=CCc1ccc(O)cc1</smiles>

[24]<smiles>C=CC(=C)CCC=C(C)C</smiles>

[25]<smiles>O=c1c(O)c(-c2ccc(O)c(O)c2)oc2cc(O)cc(O)c12</smiles>

[26]<smiles>C=CCc1ccc(OC)cc1</smiles>

[27]

FIGURA 4. Estruturas moleculares de compostos encontrados em espécies vegetais do gênero Pimenta. [17], neral. [18], linalol. [19], geraniol. [20], (E) metilisoeugenol. [21], $\boldsymbol{\gamma}$ - terpineno. [22], timol. [23], lupeol. [24], chavicol.

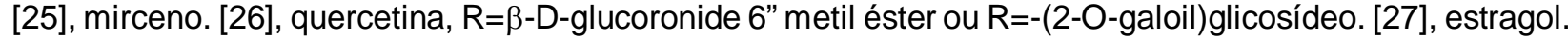

racemosa, $P$. dioica e $P$. pseudocaryophyllus e esses dados encontram-se sumarizados na Tabela 2.

Há referência à utilização das folhas da $P$. haitiensis pela população Hispaniolana no preparo de chás para gripe e problemas de garganta (Tucker et al., 1991b). Os principais componentes dos óleos essenciais dessa Pimenta (metileugenol [8] e metilchavicol [9]) são muito semelhantes aos óleos de algumas variedades de $P$. racemosa e que apresentam uso popular semelhante (Tucker et al., 1991a; 1991b). Porém não há referências de estudos in vivoe/ou in vitroque comprovem as ações da $P$. haitiensis.

\section{Atividade antiinflamatória, analgésica e antipirética}

\section{Pimenta racemosa}

Pimenta racemosa var. ozua é muito usada na medicina popular da região da República Dominicana no tratamento de diferentes doenças e sintomas, como reumatismo, dor de dente, dor abdominal, febre, pneumonia e gripe. No Haiti, é usada no combate à dor abdominal, como tempero e aperitivo para as refeições. Ao óleo essencial das folhas, quando aplicado localmente com massagens, é atribuído o efeito anti-reumático. As folhas trituradas são colocadas nos dentes para diminuir a dor. Em Cuba, o decocto da semente é usado como estimulante, enquanto que em Bahamas o decocto das folhas é usado para esse fim. Essa espécie também é usada no combate à febre na Jamaica. $\mathrm{Na}$ ilha de Granada o óleo essencial dessas plantas é usado no tratamento da diarréia (García et al., 2004).

A atividade analgésica do extrato aquoso das folhas de $P$. racemosa var. ozua foi avaliada em modelos experimentais in vivo, tais como, teste com ácido acético, teste com formalina e teste em chapa quente, utilizando camundongos. $O$ extrato aquoso reduziu de forma significativa e de maneira dose-

Rev. Bras. Pl. Med., Botucatu, v.12, n.3, p.363-379, 2010. 
TABELA 2. Resumo dos estudos de atividade biológica em espécies do gênero Pimenta.

\begin{tabular}{|c|c|c|c|c|}
\hline Espécie & $\begin{array}{l}\text { Parte } \\
\text { Usada }\end{array}$ & $\begin{array}{l}\text { Tipo de extrato ou metabólito } \\
\text { secundário }\end{array}$ & Atividade Biológica & Referência \\
\hline \multirow{2}{*}{$\begin{array}{l}\text { P. racemosa var. } \\
\text { ozua }\end{array}$} & Folhas & Extrato aquoso & Antinociceptiva & García et al. (2004) \\
\hline & Folhas & Extrato aquoso e metanólico & Anti-inflamatória & $\begin{array}{l}\text { Fernández et al. (2001); } \\
\text { García et al. (2004) }\end{array}$ \\
\hline \multirow{2}{*}{$\begin{array}{l}P . \text { racemosa } \\
\text { VNC }\end{array}$} & Folhas & Óleo essencial & Antimicrobiana & Hammer et al. (1999) \\
\hline & PNC & Oleo essencial & Antimicrobiana & Burt \& Reinders (2003) \\
\hline $\begin{array}{l}\text { P. racemosa var. } \\
\text { terebinthina }\end{array}$ & Folhas & Óleo essencial & Antimicrobiana & Saenz et al. (2004) \\
\hline $\begin{array}{l}P . \text { racemosa var. } \\
\text { grisea }\end{array}$ & Folhas & Óleo essencial & Antimicrobiana & Saenz et al. (2004) \\
\hline \multirow[t]{15}{*}{ P. dioica } & Folhas & Extrato aquoso & Antinociceptiva & Suárez et al. (1997b) \\
\hline & Folhas & Extrato alcoólico fluido & $\begin{array}{l}\text { Antinociceptiva e } \\
\text { antipirética }\end{array}$ & Benítez et al. (1998) \\
\hline & Folhas & Oleo essencial & Antidermatofítica & Hernández et al. (2003) \\
\hline & Folhas & Oleo essencial & Antimicrobiana & Oussalah et al. $(2006 ; 2007)$ \\
\hline & Folhas & $\begin{array}{l}\text { Fração aquosa final obtida do } \\
\text { fracionamento sucessivo do extrato } \\
\text { aquoso total com hexano, acetato de } \\
\text { etila e n-butanol. }\end{array}$ & $\begin{array}{l}\text { Depressora do Sistema } \\
\text { Nervoso Central; } \\
\text { Hipontensiva }\end{array}$ & $\begin{array}{l}\text { Suárez et al. (1997b); Suárez } \\
\text { et al. (1997a); Suárez et al. } \\
\text { (2000) }\end{array}$ \\
\hline & Folhas & Extrato aquoso e acetato de etila & $\begin{array}{l}\text { Anti-hemorrágica em } \\
\text { hemorragia por veneno de } \\
\text { cobra }\end{array}$ & Castro et al. (1999) \\
\hline & Folhas & Taninos & Anticâncer e antioxidante & Marzouk et al. (2007) \\
\hline & $\begin{array}{l}\text { Partes } \\
\text { aéreas }\end{array}$ & Extrato hidroalcoólico & $\begin{array}{l}\text { Antioxidante e } \\
\text { antimutagênica }\end{array}$ & Ramos et al. (2003) \\
\hline & Frutos & Extrato alcoólico & Antimicrobiana & Bara \& Vanetti (1997/1998) \\
\hline & Frutos & Extrato aquoso & Antimicrobiana & Romero et al. (2005) \\
\hline & Frutos & $\begin{array}{l}\text { Compostos polifenólicos e } \\
\text { fenilpropanóides }\end{array}$ & Antioxidante & $\begin{array}{l}\text { Kikuzaki et al. (1999); } \\
\text { Kikuzaki et al. (2000); Kluth et } \\
\text { al. (2007); Dearlove et al. } \\
(2008)\end{array}$ \\
\hline & Frutos & Quercetinas glicosídicas & $\begin{array}{l}\text { Inibidora da enzima } \\
\text { histidina descarboxilase }\end{array}$ & Nita et al. (2009) \\
\hline & Frutos & Extrato aquoso & $\begin{array}{l}\text { Inibidora da enzima } \\
\text { histona acetil transferase }\end{array}$ & Lee et al. (2007) \\
\hline & PNC & ENC & Hipoglicemiante & Barbosa Filho et al. (2005) \\
\hline & PNC & Óleo essencial & Repelente de insetos & $\begin{array}{l}\text { Gonzál ez-Quevedo et al. } \\
\text { (1997) }\end{array}$ \\
\hline \multirow{2}{*}{$\begin{array}{l}P . \\
\text { pseudocaryophyllus } \\
\text { VNC }\end{array}$} & Folhas & Extrato etanólico bruto & Antimicrobiana & Paula et al. (2009) \\
\hline & Folhas & Óleo essencial & Antimicrobiana & Lima et al. (2006) \\
\hline
\end{tabular}

PNC: Parte não citada na literatura consultada VNC: Variedade não citada na literatura consultada ENC: Extrato não citado na literatura consultada 
dependente a nocicepção induzida por ácido acético intraperitonial. No teste de formalina, o extrato também reduziu o estímulo doloroso após 1 - 5 minutos e após 20 - 25 minutos da administração da formalina, sendo que a inibição foi mais pronunciada na segunda fase. Quanto ao teste em chapa quente, ao contrário, não houve aumento significativo na latência da lambida nem no salto dos animais (García et al., 2004).

A atividade antiinflamatória do extrato aquoso e do extrato metanólico das folhas de $P$. racemosa var. ozua foi testada por meio dos protocolos experimentais do edema de pata em ratos induzido por carragenina, com administração oral do extrato; e edema de orelha em camundongos induzido por acetato de 12-o-tetradecanoilforbol (TPA), com administração tópica do extrato. O extrato demonstrou inibição significativa e dose-dependente do edema agudo nos dois modelos utilizados (Fernández et al., 2001; García et al., 2004).

Esses estudos levaram à inferência de que as ações analgésica e antiinflamatória do extrato aquoso e metanólico das folhas dessa espécie vegetal são devidas a mecanismos, provavelmente, periféricos e não centrais. Além de serem, em parte, similares aos das substâncias inibidoras da Cicloxigenase (COX), uma vez que as ações são marcadamente influenciadas pela inibição da migração de neutrófilos (Fernández et al., 2001; García et al., 2004). É necessário apontar que o lupeol [23], saponina triterpênica isolada e identificada no extrato metanólico (Fernández et al., 2001), possui atividade antiinflamatória em edema induzido por carragenina (Niero \& Malheiros, 2007).

A utilização do extrato aquoso nos protocolos experimentais contribui em grande medida para a validação do uso popular dessa espécie vegetal, uma vez que na população ela tem sido utilizada na forma de chás (infusões ou decoctos).

\section{Pimenta dioica}

A Pimenta dioica é amplamente utilizada como especiaria e condimento. Na medicina popular da América Central é utilizada para tratar hipertensão, diabetes, obesidade, problemas digestivos, gripe, resfriado e febre. No Caribe é utilizada para dores abdominais e cólicas menstruais (Suárez et al., 1997b).

Diferentes extratos (aquoso, hexano, acetato de etila, n-butano e alcoólico) obtidos da folha de $P$. dioica foram testados em ratas albinas normotensas e hipertensas. Após avaliação do screening hipocrático foi detectada pronunciada atividade analgésica do extrato aquoso (Suárez et al., 1997b).

As atividades analgésica e antipirética do extrato alcoólico fluido das folhas de $P$. dioica também foram avaliadas em ensaios biológicos in vivo. A atividade analgésica foi investigada utilizando-se a técnica de contorções induzidas por agentes químicos em ratas albinas Swiss. Para a atividade antipirética foram utilizados coelhos Chinchilla machos que receberam endotoxina de $E$. coli como agente pirogênico. $O$ extrato fluido de $P$. dioica produziu analgesia (1.650 $\mathrm{mg} \mathrm{Kg}^{-1}$ ) e efeito antipirético (412 $\mathrm{mg} \mathrm{Kg}^{-1}$ ) comparável aos do lbuprofeno (200 $\mathrm{g} \mathrm{Kg}^{-1}$ ), nesse modelo experimental corroborando in vivo o uso popular dessa espécie vegetal (Benítez et al., 1998).

\section{Atividade antimicrobiana}

\section{Pimenta racemosa}

Dentre 52 óleos e extratos de plantas investigados na Austrália quanto à atividade antimicrobiana, o óleo essencial das folhas de $P$. racemosa foi capaz de inibir o crescimento de Acinetobacter baumanii, Aeromonas veroniibiogrupo sobria, Candida albicans, Enterococcus faecalis, Escherichia coli, Klebisiella pneumoniae, Pseudomonas aeruginosa, Salmonella enterica subsp. enterica sorotipo typhimurium, Serratia marcescens e Staphylococcus aureus a concentração $\leq 2.0 \%$ (v/v) (Hammer et al., 1999).

O óleo essencial de $P$. racemosa adquirido de fabricante germânico apresentou atividade antibacteriana frente à Escherichia coli O157:H7, bactéria muito comum em gêneros alimentícios. Nesse estudo, realizado na Holanda, foram testados outros quatro óleos essenciais, de Origanum vulgare (orégano), Thymus vulgaris (timo, variedade clara e vermelha) e Syzygium aromaticum (cravo). Os óleos essenciais de orégano e timo apresentaram propriedades colicidas e colistáticas maiores, seguidos pelo óleo essencial da $P$. racemosa. Tais resultados são atribuídos à presença de carvacrol, timol [22], citral [16, 17], eugenol [2], dentre outros componentes nesses óleos essenciais e fomentam estudos de utilização desses óleos na indústria alimentícia (Burt \& Reinders, 2003).

A Pimenta racemosa var. terebinthina e a Pimenta racemosa var. grisea, usadas no Caribe para tratar dores e inflamações, tiveram os óleos essenciais de suas folhas avaliados quanto a atividade antibacteriana. A variedade grisea foi especialmente ativa contra bactérias Gram positivas (Bacillus cereus, B. megaterium, $B$. subtilis e Staphylococcus aureus) e algumas Gram negativas (Klebsiella pneumoniae, Serratia marcescens, Salmonella thyphimurium e Escherichia coli). Tais resultados sugerem que 0 efeito antimicrobiano exibido pela variedade grisea pode ser atribuído à presença, no óleo essencial, dos compostos 4-metoxi-isoeugenol e 4metoxieugenol. E o moderado efeito da variedade terebinthina pode ser atribuído à presença dos

Rev. Bras. PI. Med., Botucatu, v.12, n.3, p.363-379, 2010. 
componentes majoritários acetato de $\alpha$-terpineol e $\alpha$-terpineol [11] (Saenz et al., 2004).

\section{Pimenta dioica}

O extrato alcoólico dos frutos de $P$. dioica, utilizando o método de difusão em agar, demonstrou eficiência na inibição do crescimento de Yersinia enterocolitica. Esta atividade foi também atribuída ao alto conteúdo de eugenol presente no óleo essencial do fruto (Bara \& Vanetti, 1997/1998).

Os óleos essenciais de quatro espécies vegetais cubanas, dentre elas a $P$. dioica, foram avaliados in vitro quanto à atividade antidermatofítica. Dos quatro óleos examinados, o das folhas de $P$. dioica demonstrou ser o mais ativo contra os dermatófitos Microsporum canis, Trichophyton mentagrophytese Trichophyton rubrum a uma Concentração Inibitória Mínima (CIM) de 0,31 $\mathrm{mg} \mathrm{mL}^{-1}$. Tal atividade foi atribuída ao alto conteúdo de eugenol [2] desse óleo essencial, uma vez que foram realizados os mesmos testes com o eugenol puro e este demonstrou CIM de 0,16 - 0,33 $\mathrm{mg} \mathrm{m}^{\mathrm{L}-1}$ (Hernández et al., 2003).

O óleo essencial das folhas de $P$. dioica, rico em eugenol [2], mirceno [25] e geraniol [19], apresentou atividade antimicrobiana frente E.coli O157:H7, Salmonella typhimurium, Staphylococcus aureus, Listeria monocytogenes e Pseudomonas putida isolada de amostras de carne (Oussalah et al., 2006; 2007). O extrato aquoso dos frutos de $P$. dioica demonstrou atividade antibacteriana para $S$. aureus (Romero et al., 2005).

\section{Pimenta pseudocaryophyllus}

Os extratos etanólicos brutos das folhas de P. pseudocaryophyllus coletadas em duas localidades geográficas brasileiras apresentaram atividade antimicrobiana frente as bactérias Gram positivas $S$. aureus, Micrococcus luteus, M. roseus, Bacillus cereus, $B$. subtilis e $B$. stearothermophylus. Foram ativos ainda, frente as Gram negativas Pseudomonas aeruginosa, isolados clínicos de $P$. stutzerie frente a levedura Candida albicans. Compostos fenólicos, taninos, flavonóides e óleos essenciais foram identificados na droga vegetal e podem estar envolvidos na ação antimicrobiana (Paula et al., 2009).

O óleo essencial das folhas de dois espécimes de P. pseudocaryophyllus, coletados em outras duas localidades brasileiras, demonstrou diferentes padrões de atividade antimicrobiana frente Candida albicans (ATCC 10231), E. coli (ATCC 8739), $P$. aeruginosa (ATCC 9027) e S. aureus (ATCC 6538). As variações na sensibilidade, observadas nesse estudo, devem-se à composição química dos óleos essenciais dos espécimes, uma vez que o componente majoritário em um deles era o eugenol enquanto no outro era o 4-metileugenol (Lima et al., 2006).

\section{Atividade cardiovascular}

\section{Pimenta dioica}

A fim de validar alguns dos usos etnofarmacológicos da $P$. dioica foi realizado um estudo in vivo com a administração aguda e subaguda de extratos (aquoso total e alcoólico) e de frações (hexano, acetato de etila, n-butanol e aquosa final) de folhas de $P$. dioica a ratas albinas conscientes normotensas e hipertensas. Pronunciado efeito depressor sobre o Sistema Nervoso Central (SNC) foi observado com a fração aquosa final. Quando essa mesma fração foi administrada oralmente, não foi observado, nesse estudo, efeito algum sobre a pressão arterial sistólica. Provavelmente, o efeito depressor sobre o SNC poderia estar implicado no efeito terapêutico hipotensivo, atribuído pela medicina popular. De qualquer forma esse estudo tornou evidente que as substâncias biologicamente ativas persistem na fração aquosa do extrato (Suárez et al., 1997b).

Em outro estudo esses mesmos autores avaliaram a atividade hipotensiva dos extratos alcoólico e aquoso de folhas $P$. dioica e de frações do extrato aquoso, em ratos machos normotensos anestesiados. A administração intravenosa do extrato aquoso produziu queda significativa e dosedependente da pressão arterial, maior que a do extrato alcoólico, sendo que a atividade hipotensiva mais pronunciada foi observada na fração aquosa final (Suárez et al., 1997a).

Essa fração foi utilizada por via intravenosa em outro modelo experimental utilizando ratos espontaneamente hipertensos (SHR) e anestesiados. O objetivo, além de avaliar a atividade hipotensiva nessas condições, era pesquisar possíveis mecanismos de ação hipotensiva da fração aquosa. Para isso foram utilizados também protocolos experimentais em que antagonistas farmacológicos foram administrados aos ratos SHR antes da injeção da fração aquosa. Foi possível verificar que a ação hipotensiva parece não ser mediada por receptores colinérgicos, nem por receptores $\alpha$ ou $\beta$ adrenérgicos. $E$ que o efeito hipotensor independe da quantidade de íons $\mathrm{K}^{+}, \mathrm{Ca}^{2+} \mathrm{Na}^{+}$ou $\mathrm{Mg}^{2+}$ presentes no extrato aquoso total. A fração aquosa final pode possuir ação vasodilatora por atuação direta sobre a musculatura lisa dos vasos que ainda precisa ser investigada (Suárez et al., 2000).

\section{Outros tipos de atividades farmacológicas pesquisadas em $P$. dioica}

Artigo de revisão sobre plantas com ação hipoglicemiante e constituintes ativos, elaborado por Barbosa Filho et al. (2005), cita a Pimenta officinalis (allspice), dos Estados Unidos da América, como possuidora dessa ação. $O$ trabalho citado utilizou 
protocolo experimental envolvendo cultura de células, porém a parte da planta empregada e o tipo de extrato não foram mencionados. Segundo Landrum (1986), o nome Pimenta officinalis era utilizado para designar a espécie hoje conhecida como Pimenta dioica.

O extrato hidroalcoólico das partes aéreas de Pimenta dioca apresentou propriedades antioxidantes em modelos experimentais nos quais foram utilizados o radical 1,1-difenil-2-picrilidrazil (DPPH), o teste de inibição da peroxidação de lipídeos e o teste de inibição do ataque a desoxiglicose por radicais ${ }^{\bullet} \mathrm{OH}$. Além disso, em ensaio antimutagênico com E. coli IC 188, P. dioica demonstrou ser capaz de prevenir danos ao DNA provocados por ter-butil hidroperóxido (TBH). Essa propriedade pode estar relacionada à presença de eugenol [2] no extrato testado, uma vez que esse componente também inibiu a mutagênese oxidativa por TBH em E. coli (Ramos et al., 2003).

Galoilglicosídeos (Tabela 1) isolados dos frutos de Pimenta dioica mostraram atividade antiradicais livre aproximadamente equivalente à do ácido gálico contra o radical 1,1-difenil-2-picrilidrazil (Kikuzaki et al., 2000). E fenilpropanóides (Tabela 1), também isolados dos frutos, inibiram a auto-oxidação do ácido linoleico em um sistema água-álcool (Kikuzaki et al., 1999).

Creme fabricado com base hidrossolúvel e $1 \%$ de óleo essencial de Pimenta dioica foi testado em grupo de combatentes cubanos quanto à atividade repelente de insetos. No protocolo experimental utilizou-se creme placebo, com a mesma base, porém sem o óleo essencial, em outro grupo de combatentes. Os resultados demonstraram repelência de $100 \%$ no grupo tratado com creme e óleo essencial e $47,36 \%$ no grupo tratado com placebo, sendo essa diferença estatisticamente significativa (González-Quevedo et al., 1997).

Os extratos aquoso e acetato de etila, das folhas de Pimenta dióica, foram capazes de neutralizar completamente a atividade hemorrágica induzida pelo veneno da cobra Bothrops asperem bioensaio com camundongos. Análises químicas revelaram que os extratos possuíam os flavonóides quercetina [6] e catequina [7], além de taninos condensados. Esses compostos provavelmente atuaram como quelantes do íon zinco requerido para a atividade catalítica das metaloproteinases hemorrágicas do veneno (Castro et al., 1999).

Recentemente, os compostos polifenólicos presentes em extratos de diversos vegetais, dentre eles, extratos de frutos de $P$. dioica, foram estudados quanto ao potencial antioxidante. Doenças ligadas ao stress oxidativo, tais como, aterosclerose e câncer podem ser prevenidas por substâncias com tais propriedades (Kluth et al., 2007; Dearlove et al., 2008). Taninos com atividades anticâncer e antioxidante foram isolados e identificados em extratos da folha de P. dioica (Marzouk et al., 2007). Além disso, duas quercetinas glicosídicas [quercetina 3-O- $\beta$-D-glucuronide 6" metil éster e quercetina 3-O-(2-O-galoil) glucoside] [26] isoladas de extratos dos frutos de $P$. dioica foram identificadas como potentes inibidoras da enzima histidina descarboxilase. Essa enzima promove a formação de histamina a partir de histidina, portanto a inibição representa benefícios em processos alérgicos e outros quadros patológicos mediados pela histamina (Nita et al., 2009).

O extrato aquoso, obtido a quente (refluxo), de frutos secos de $P$. dioica exibiu efeito inibitório sobre a enzima histona acetil transferase (HAT). Há evidências de que HAT desempenhe importante papel na causa e progressão de alguns tipos de câncer, portanto esses resultados apontam para um uso potencial desse vegetal como antineoplásico (Lee et al., 2007).

\section{Avaliação da toxicidade de Pimenta racemosa e Pimenta dioica}

A toxicidade aguda do extrato aquoso das folhas de $P$. racemosa var. ozua foi avaliada por via intraperitoneal em camundongos albinos machos. A $\mathrm{DL}_{50}$ encontrada foi de $287 \pm 12,9 \mathrm{mg}$ de resíduo $\mathrm{Kg}^{-1}$. Considerou-se que há carência de efeitos tóxicos nas dosagens usuais, para o extrato testado (García et al., 2004).

A toxicidade oral aguda do extrato fluido das folhas de $P$. dioica foi avaliada em modelo experimental com camundongos machos Swiss utilizando três níveis de dose. $\mathrm{O}$ valor de $\mathrm{DL}_{50}$ obtido $\left(2,56 \mathrm{~g} \mathrm{Kg}^{-1}\right)$ permitiu classificar o extrato fluido como não tóxico (Benítez et al., 1998).

Esse mesmo valor de $\mathrm{DL}_{50}$ foi encontrado por Parra et al. (2001) para extrato fluido de $P$. dioica nas mesmas condições anteriores. $O$ interessante é que nesse estudo os autores compararam as $\mathrm{DL}_{50}$ de diversos extratos vegetais com os valores de $\mathrm{LC}_{50}$ (concentração letal média) desses mesmos extratos, obtidas em modelo experimental in vitro com Artemia salina L. (Artemiidae). Puderam verificar correlação estatística entre os resultados de ambos os testes. O que torna o teste in vitro uma alternativa útil na triagem da atividade tóxica de extratos de plantas, com as vantagens de ter menor custo, maior simplicidade e não utilizar animais de laboratório.

\section{CONCLUSÃO}

As características botânicas macroscópicas e microscópicas descritas neste trabalho, tais como as referentes à proeminência das nervuras laterais e central das folhas, facilmente visíveis, presença de numerosos estames, ovários inferiores, frutos do tipo

Rev. Bras. Pl. Med., Botucatu, v.12, n.3, p.363-379, 2010. 
baga, presença de ritidoma na casca e cavidades secretoras de substâncias terpênicas nas folhas, corroboram a classificação desse gênero dentro da família Myrtaceae.

Estudos científicos respaldaram a maioria dos usos medicinais que pessoas, de diversas partes do mundo, fazem das plantas do gênero Pimenta. Além disso, propriedades farmacológicas não referidas pela população foram também observadas em modelos experimentais. Muitas dessas ações foram atribuídas aos componentes majoritários dos óleos essenciais, na maioria, presentes nas folhas. No entanto, outros metabólitos secundários também podem contribuir para essas atividades, pois saponinas, compostos fenólicos, taninos e flavonóides têm sido identificados nessas espécies.

As espécies mais estudadas são a $P$. racemosa, $P$. dioica e a $P$. pseudocaryophyllus. A composição química dos óleos essenciais dessas plantas é fundamental para determinar a atividade das mesmas, e, como muitas têm componentes em comum, também podem ter ações semelhantes. Por isso, as demais espécies, provavelmente, têm importantes ações farmacológicas que merecem ser investigadas.

Pelo fato de muitas atividades terem sido estudadas e comprovadas, e as pesquisas demonstrarem baixa toxicidade em modelos experimentais in vivo para algumas espécies, justificase a continuidade das pesquisas em espécies desse gênero.

\section{REFERÊNCIA}

ABAUL, J.; BOURGEOIS, P.; BESSIERE, J.M. Chemical composition of the essential oils of chemotypes of Pimenta racemosa var. racemosa (P. Miller) J. W. Moore (Bois d'Inde) of Guadeloupe (F.W.I.). Flavour and Fragrance Journal, v.10, n.5, p.319-21, 1995.

BARA, M.T.F.; VANETTI, M.C.D. Estudo da atividade antimicrobiana de plantas medicinais, aromáticas e corantes naturais. Revista Brasileira de Farmacognosia, v.7/8, n.1/ 2, p.22-34, 1997/1998.

BARBOSA FILHO, J.M. et al. Plants and their active constituents from South, Central, and North America with hypoglycemic activity. Brazilian Journal of Pharmacognosy, v.15, n.4, p.392-413, 2005.

BENÍTEZ, A.; TILLÁN, J.; CABRERA, Y. Actividad analgésica y antipirética de un extracto fluido de Pimenta dioica L. y evaluación de su toxicidad aguda oral. Revista Cubana de Farmacia, v.32, n.3, p.198-203, 1998.

BRASIL. Decreto n. 5.813, de 22 de junho de 2006. Aprova a Política Nacional de Plantas Medicinais e Fitoterápicos e dá outras providências. Diário Oficial da União, Brasília, DF, 23 de junho de 2006a.

BRASIL. Ministério da Saúde. Portaria n. 971, de 3 de maio de 2006. Aprova a Política Nacional de Práticas Integrativas e Complementares (PNPIC) no sistema
Único de saúde. Diário Oficial da União, Brasília, DF, 4 de maio de 2006b.

BURT, S.A.; REINDERS, R.D. Antibacterial activity of selected plant essential oils against Escherichia coli O157:H7. Letters in Applied Microbiology, v.36, p.1627, 2003.

CASTRO, O. et al. Neutralización del efecto hemorrágico inducido por veneno de Bothrops asper (Serpentes: Viperidae) por extractos de plantas tropicales. Revista de Biología Tropical, v.47, n.3, p.605-16, 1999.

CUNHA, A.P.; CAVALEIRO, C.; SALGUEIRO, L. Fármacos aromáticos (plantas aromáticas e óleos essenciais). In: CUNHA, A.P. (Coord.). Farmacognosia e fitoquímica. Lisboa: Fundação Calouste Gulbenkian, 2005. p.339401.

DEARLOVE, R.P. et al. Inhibition of protein glycation by extracts of culinary herbs and spices. Journal of Medical Food, v.11, n.2, p.275-81, 2008.

FERNÁNDEZ, A. et al. Anti-inflammatory effect of Pimenta racemosa var. ozua and isolation of the triterpene lupeol. II Fármaco, v.56, p.335-8, 2001.

GARCÍA, M.D. et al. Antinociceptive and anti-inflammatory effect of the aqueous extract from leaves of Pimenta racemosa var. ozua (Mirtaceae). Journal of Ethnopharmacology, v.91, p.69-73, 2004.

GONZÁLEZ-QUEVEDO, M. et al. Uso de la crema repelente de Pimenta dioica por combatientes de una unidad militar. Revista Cubana de Medicina Militar, v.26, n.2, p.94-7, 1997.

HAMMER, K.A.; CARSON, C.F.; RILEY, T.V. Antimicrobial activity of essential oils and other plant extracts. Journal of Applied Microbiology, v.86, p.985-90, 1999.

HERNÁNDEZ, L. et al. Actividad antidermatofítica in vitro de aceites esenciales. Revista Cubana de Plantas Medicinales, v.8, n.2, 2003. Disponível em: <http:// scielo.sld.cu/scielo.php?script=sci_arttext\&pid=S1028$47962003000200004 \& \mathrm{lng}=\mathrm{es} \& \mathrm{nrm}=\mathrm{iso}>$. Acesso em: 2 jul. 2007.

JOLY, A.B. Botânica: introdução à taxonomia vegetal. 13.ed. São Paulo: Companhia Editora Nacional, 2002. 778p.

JUDD, W.S. et al. Plant systematics: a phylogenetic approach. Sunderland: Sinauer, 1999. 464p.

KIKUZAKI, $\mathrm{H}$. et al. Antioxidative phenylpropanoids from berries of Pimenta dioica. Phytochemistry, v.52, p.130712, 1999.

KIKUZAKI, H. et al. Galloylglucosides from berries of Pimenta dioica. Journal of Natural Products, v.63, p.74952, 2000.

KIKUZAKI, $\mathrm{H}$. et al. Phenolic glycosides from berries of Pimenta dioica. Journal of Natural Products, v.71, p.8615, 2008.

KLUTH, D. et al. Modulation of pregnane $X$ receptor-and eletrophile responsive element-mediated gene expression by dietary polyphenolic compounds. Free Radical Biology \& Medicine, v.42, p.315-25, 2007. LANDRUM, L.R. Flora Neotropica: monograph 45 Campomanesia, Pimenta, Blepharocalyx, Legrandia, Acca, Myrrhinium, and Luma (Myrtaceae). New York: Organization for Flora Neotropica, 1986. 179p.

LANDRUM, L.R.; KAWASAKI, M.L. The genera of Myrtaceae in Brazil: an illustrated synoptic treatment and identification keys. Brittonia, v.49, n.4, p.508-36, 1997.

LAPA, A.J. et al. Plantas medicinais: métodos de 
avaliação da atividade farmacológica. Campinas: UNIFESP/EPM, 2008. 144p.

LEE, Y. et al. Anti-histone acetyltransferase activity from Allspice extracts inhibits androgen receptor-dependent prostate cancer cell growth. Bioscience Biotechnology \& Biochemistry, v.71, n.11, p.2712-9, 2007.

LIMA, M.E.L. et al. Antimicrobial activity of the essential oil from two specimens of Pimenta pseudocaryophyllus (Gomes) L.R. Landrum (Myrtaceae) native from São Paulo State - Brazil. Pharmacologyonline, v.3, p.589-93, 2006. MARONGIU, B. et al. Comparative analysis of supercritical $\mathrm{CO}_{2}$ extract and oil of Pimenta dioica leaves. Journal of Essential Oil Research, v.17, p.530-2, 2005.

MARZOUK, M.S.A. et al. Anticancer and antioxidante tannins from Pimenta dioica leaves. Zeitschrift für Naturforschung C - A Journal of Biosciences, v.62, n.78, p.526-36, 2007.

MINOTT, D.A.; BROWN, H.A. Differentiation of fruiting and non-fruiting Pimenta dioica (L.) Merr. trees based on composition of leaf volatiles. Journal of Essential Oil Research, v.19, p.354-7, 2007.

NAKAOKA-SAKITA, M. et al. Óleo essencial de Pimenta pseudocaryophyllus var. pseudocaryophyllus (Gomes) Laudrum (MYRTACEAE) I: cromatografia a gás/ espectrometria de massa (CG/EM). Revista do Instituto Florestal, v.6, p.53-62, 1994.

NIERO, R.; MALHEIROS, A. Principais aspectos químicos e biológicos de terpenos. In: YUNES, R.A.; CECHINEL FILHO, V. (Orgs.). Química de produtos naturais, novos fármacos e a moderna farmacognosia. Itajaí: Univali, 2007. p.237-57.

NITTA, Y.; KIKUZAKI, H.; UENO, H. Inhibitory activity of Pimenta dioica extracts and constituents on recombinant human histidina descarboxilase. Food Chemistry, v.113, p.445-9, 2009.

OUSSALAH, M. et al. Antimicrobial effects of selected plant essential oils on the growth of a Pseudomonas putida strain isolated from meat. Meat Science, v.73, p.236-44, 2006.

OUSSALAH, M. et al. Inhibitory effects of selected plant essential oils on the growth of four pathogenic bacteria: $E$. coli O157:H7, Salmonella typhimurium, Staphylococcus aureus and Listeria monocytogenes. Food Control, v.18, p.414-20, 2007.

PARRA, A.L. et al. Comparative study of the assay of Artemia salina $\mathrm{L}$. and the estimate of the medium lethal dose (LD50 value) in mice, to determine oral acute toxicity of plant extracts. Phytomedicine, v.8, n.5, p.395-400, 2001. PAULA, J.A.M. et al. Antimicrobial activity of the crude ethanol extract from Pimenta pseudocaryophyllus. Pharmaceutical Biology, v.47, n.10, p.987-93, 2009.

PAULA, J.A.M. Estudo farmacognóstico e avaliação da atividade antimicrobiana das folhas de Pimenta pseudocaryophyllus (Gomes) L. R. Landrum Myrtaceae. 2006. 139p. Dissertação (Mestrado em Biologia) - Instituto de Ciências Biológicas, Universidade Federal de Goiás, Goiânia.

PAULA, J.A.M. et al. Estudo farmacognóstico da casca de Pimenta pseudocaryophyllus (Gomes) L. R. Landrum Myrtaceae. Revista Eletrônica de Farmácia, v.3, n.2, p.13, 2006. Disponível em: <www.farmacia.ufg.br>. Acesso em: 6 out. 2007.

PAULA, J.A.M. et al. Estudo farmacognóstico das folhas de Pimenta pseudocaryophyllus (Gomes) L. R. Landrum Myrtaceae. Revista Brasileira de Farmacognosia, v.18, n.2, p.265-78, 2008.

PINO, J.A.; BELLO, A.; URQUIOLA, A. The leaf oil of Pimenta adenoclata (Urb) Burret from Cuba. Journal of Essential Oil Research, v.14, p.400-1, 2002.

RAMOS, A. et al. Screening of antimutagenicity via antioxidant activity in Cuban medicinal plants. Journal of Ethnopharmacology, v.87, p.241-6, 2003.

RANG, H.P. et al. Farmacologia. 6.ed. Rio de Janeiro: Elsevier, 2007. 920p.

REBOLLAR, S.; QUINTANAR, A. Anatomía y usos de la madera de ocho especies tropicales de Quintana Roo, México. Revista de Biología Tropical, v.46, n.4, p.104757, 1998.

RODRIGUES, V.E.G.; CARVALHO, D.A. Plantas medicinais no domínio dos cerrados. Lavras: UFLA, 2001. 180p.

ROMERO, C.D. et al. Antibacterial properties of common herbal remedies of the southwest. Journal of Ethnopharmacology, v.99, p.253-7, 2005.

SAENZ, M.T. et al. Antibacterial activity of essential oils of Pimenta racemosa var. terebinthina and Pimenta racemosa var. grisea. Fitoterapia, v.75, p.599-602, 2004. SANTOS, B.C.B. et al. Isolation of chavibetol from essential oil of Pimenta pseudocaryophyllus leaf by highspeed counter-current chromatography. Journal of Chromatography A, v.1216, p.4303-6, 2009.

SCHULZ, V.; HÄNSEL, R.; TYLER, V.E. Fitoterapia racional: um guia de fitoterapia para as ciências da saúde. 4.ed. Barueri: Manole, 2002. 386p.

SILVA, K.L.; CECHINEL FILHO, V. Plantas do gênero Bauhinia: composição química e potencial farmacológico. Química Nova, v.25, n.3, p.449-54, 2002.

SIMÕES, C.M.O.; SPITZER, V. Óleos voláteis. In: SIMÕES, C.M.O. et al. (Orgs.). Farmacognosia: da planta ao medicamento. 5.ed. rev.ampl. Porto Alegre/Florianópolis: Editora da UFRGS/Editora da UFSC, 2004. p.467-95.

SOUZA, V.C.; LORENZI, H. Botânica sistemática: guia ilustrado para identificação das famílias de angiospermas da flora brasileira, baseado em APG II. Nova Odessa: Instituto Plantarum de Estudos da Flora, 2005. 640p.

SUÁREZ, A.; ULATE, G.; CICCIO, J.F. Cardiovascular effects of ethanolic and aqueous extracts of Pimenta dioica in Sprague-Dawley rats. Journal of Ethnopharmacology, v.55, p.107-11, 1997a.

SUÁREZ, A.; ULATE, G.; CICCIO, J.F. Efectos de la administración aguda y subaguda de extractos de Pimenta dioica (Myrtaceae) en ratas albinas normotensas e hipertensas. Revista de Biología Tropical, v.44, n.1, p.39-45, 1997b.

SUÁREZ, A.; ULATE, G.; CICCIO, J.F. Hypotensive action of an aqueous extract of Pimenta dioica (Myrtaceae) in rats. Revista de Biología Tropical, v.48, n.1, p.53-8, 2000. THE NEW YORK BOTANICAL GARDEN. Disponível em: $<$ www.nybg.org/bsci/hcol/sebc/Myrtaceae.html>. Acesso em: 24 ago. 2004.

TUCKER, A.O. et al. Volatile leaf oils of Caribbean Myrtaceae. I. Three varieties of Pimenta racemosa (Miller) J. Moore of the Dominican Republic and the commercial bay oil. Journal of Essential Oil Research, v.3, p.3239,1991a.

TUCKER, A.O. et al. Volatile leaf oils of Caribbean Myrtaceae.

Rev. Bras. PI. Med., Botucatu, v.12, n.3, p.363-379, 2010. 
III. Pimenta haitiensis (Urban) Landrum of the Dominican Republic. Journal of Essential Oil Research, v.3, p.4713,1991b.

TUCKER, A.O.; MACIARELLO, M.J.; LANDRUM, L.R. Volatile leaf oils of Caribbean Myrtaceae. II. Pimenta dioica (L.) Merr. of Jamaica. Journal of Essential Oil Research, v.3, p.195-6, 1991.

TUCKER, A.O.; MACIARELLO, M.J.; LANDRUM, L.R. Volatile leaf oils of Caribbean Myrtaceae. IV. Pimenta jamaicensis (Britton \& Harris) Proctor of Jamaica. Journal of Essential Oil Research, v.4, p.93-4, 1992a.

TUCKER, A.O.; MACIARELLO, M.J.; LANDRUM, L.R. Volatile leaf oils of Caribbean Myrtaceae. V. Pimenta obscura Proctor of Jamaica. Journal of Essential Oil Research, v.4, p.195-6, 1992b.

VOLPATO, G.; GODÍNEZ, D. Ethnobotany of Pru, a traditional Cuban refreshment. Economic Botany, v.58, n.3, p.381-95, 2004.

WORLD HEALTH ORGANIZATION. Quality control methods for medicinal plant materials. Geneva: WHO, 1998. 115p.

YUNES, R.A.; CECHINEL FILHO, V. Novas perspectivas dos produtos naturais na química medicinal moderna. In: YUNES, R.A.(Org.). Química de produtos naturais, novos fármacos e a moderna farmacognosia. Itajaí: Univali, 2007. p.9-32.

YUNES, R.A.; CECHINEL FILHO, V. Breve histórico da química de plantas medicinais: sua importância na atual concepção de fármaco segundo os paradigmas ocidental e oriental. In: YUNES, R.A.; CALIXTO, J.B. (Eds.). Plantas medicinais sob a ótica da química medicinal moderna. Chapecó: Argos, 2001. p.17-44. 